Колоӥз Ж. В.

доктор філологічних наук, професор, завідувач кафедри української мови ДВНЗ «Криворізький національний університет»

\title{
ЛІНГВОМЕНТАЛЬНА РЕПРЕЗЕНТАЦІЯ КОНЦЕПТУ ДЕРЖАВА В УКРАЇНСЬКОМУ АФОРИСТИЧНОМУ ПРОСТОРІ
}

У статті йдеться про лінгвоментальну репрезентацію концепту ДЕРЖАВА 6 українському афористичному просторі. Досліджено семантичне наповнення відповідного концепту в індивідуально-авторських висловленнях крізь призму ядерних та периферійних елементів. Акиентовано на деяких прийомах досягнення стилістичного ефекту.

Ключові слова: кониепт, афоризм, афористичне висловлення, афористичний простір, семантичне наповнення.

В статье идет речь о лингвоментальной репрезентации кониепта ГОСУДАРСТВО в украинском афористическом пространстве. Исследуется семантическое наполнение соответствующего концепта в индивидуально-авторских высказываниях через призму ядерных и периферийных элементов. Акиентируется внимание на некоторых приемах достижения стилистического эффекта.

Ключевые слова: конщепт, афоризм, афористическое высказывание, афористическое пространство, семантическое наполнение.

The article deals with the linguistic and mental STATE concept represented in the Ukrainian aphorisms stock. The paper investigates the concept semantics content revealed inthe individual author's expressions with nuclear and peripheral components. The article is also focused on some techniques and devices used to achieve appropriate stylistic effect.

Keywords: concept, aphorism, aphoristic expression, aphoristic stock, semantics content.

Упродовж останніх десятиліть паремійний корпус загалом й афористичний зокрема неодноразово ставали об’єктом зацікавлення науковців різних царин. Попри посилений інтерес до відповідних одиниць чимало питань, пов'язаних із дослідженням як власне паремій, або народних афоризмів, так i так званих авторських афоризмів, залишаються дискусійними [Колоїз 2014].

Зазвичай афоризмами прийнято називати короткі, глибокі за змістом i закінчені у смисловому плані судження, що належать певному автору й образно оформлені. Витлумачення афоризмів частково модифікуються залежно від набору диференційних ознак, виокремлюваних тим чи тим ученим.

Не викликає принципових заперечень і твердження про те, що авторській афоризм вирізняється не лише оригінальною, влучною, виразною, легкою для запам’ятовування формою, але й планом змісту, що являє собою «продукт 
узаємодії узагальненого значення, дискурсивного змістового «прирощення» $\mathrm{i}$ прагматичної установки» [Семененко 2011 : 119].

Афоризми, маніфестуючи передовсім світоглядно-естетичні пріоритети їх автора, водночас засвідчують культурно-національну специфіку, відображають національну мовну картину світу й сприймаються як лінгвокультурні універсалії, репрезентують ті чи ті концепти української культури.

Аксіоматично звучать твердження про те, що «концепт увесь час перебуває в динаміці, його грані шліфуються, а глибина вертикального культурно-національного контексту збільшується» i що «зміст концепту як основної одиниці ментальності, ментальної сутності визначається всією розмаїтістю контекстів його вживання й залежить від світоглядних домінант» [Ужченко $2007: 292]$.

Одним із ключових концептів української культури є концепт ДЕРЖАВА, що зазвичай сприймається крізь призму лексичного значення «апарат політичної влади в суспільстві» або «країна 3 таким апаратом політичної влади» (в українській мові іменник держава є похідним від дієслова держати - «тримати, управляти»: Держава - держить. Бо вона держава. У неї скіпетр влади у руціi (Л. Костенко).

Український афористичний простір певною мірою модифікує семантичне наповнення відповідного концепту. Причому, зауважимо, його індивідуальноавторська інтерпретації досить рідко супроводжується позитивними емоціями (Держава - изе апарат для осягнення мети начуії (Д. Донцов); Держави стоять не на династї, а на внутрішній єдності $i$ силі народу (О. Теліга). Відштовхуючись від наукового потрактування держави («політичне утворення 3 чітко визначеною територією, формальний інститут, який $\epsilon$ формою організації тієї чи тієї спільноти під управлінням уряду»), очевидно, варто було б говорити про такі універсальні висловлення, які «конденсовано в імперативній чи дефінітивній формі подають розгорнуті судження» про «державний апарат», «систему органів державної влади», «відтворюють психоментальні механізми» їх нормативного відображення. Щоправда, такі 


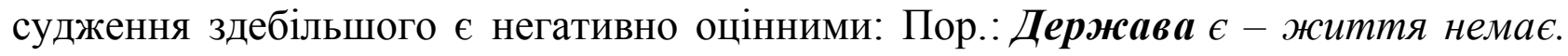
Очевидно, тому, щзо воно надто добре у тих, хто представляє держсаву (Ю. Береза); Держкава так надійно охороняє наші права, щзо доводиться лише обов'язки виконувати (В. Краснюк); Держава потурбувалася про спокійну старість пересічних громадян - на них навіть злодї не звертають уваги, взяти-то нічого (О. Домницький); Держкава $є$ сукупність окремо взятих урядовиів, які надають особистому зиску статус суспільних інтересів (С. Скоробагатько); Діагноз небезпечно хворій держкві: витік мізків за кордон (Г. Яблонський); Демократична держава ідеальна, якщзо в ній однакова кількість дурних і розумних. I, звичайно ж, - чесних і злодїв (В. Голобородько).

Концепт ДЕРЖАВА як інтерпретатор відповідного смислу в українському афористичному просторі постійно модифікується, конкретизується, уточнюється. Актуалізується насамперед художньо-семантичне наповнення ДЕРЖАВА ЗЕМЛЯ (Історії ж бо пишуть на столі. Ми ж пишем кров'ю на свойй землі (Л. Костенко); ДЕРЖАВА - КРАЇНА (Ми бездомні у своєму домі, ми безпритульні у своїй краӥні (Л. Костенко); Завдяки історичній пам'яті людина стає особистістю, народ - нацуією, краӥна - держкавою (М. Грушевський); ДЕРЖАВА - БАТЬКІВЩИНА (Кількість украӥнців подвоӥться, якщо почнуть думати не тільки про себе, а й про Батьківщину (В. Голобородько); Коли державі щуось від нас потрібно, вона називає себе Батьківщиною (С. Скоробагатько); ДЕРЖАВА - УКРАЇНА (Дай, Боже, нам любити Украӥну понад усе сьогодні - маючи, щзоб не довелось потім гірко любити - втративщи (В. Чорновіл); Не Украӥна для нас, а ми для Украӥни! (Д. Мирон); Колись в Україні був Бандера, а нині банд ера (В. Ігнатенко); Порятунок Украӥни - у рятуванні од ї̈ рятувальників (В. Шамша); Росія $і$ Україна схожі, як дві пляшки мінералки, тільки одна з газом, а друга - без (А. Корчинський). У такому разі відповідні лексеми на зразок земля, краӥна, держава отримують і відповідні атрибутивні поширювачі у вигляді присвійних займенників своя / наша. Пор.: Нікчемний той народ, який не шанує своїх героїв, щзо віддали життя за свободу, незалежність своєї держави (Й. Сліпий); Якщуо ви любите свою 
держсаву, живіть недовго - їй иее вигідно (С. Скоробагатько); У намій краӥні всього вистачає, інша справа, щзо не всім (В. Даньків), де загалом актуалізується значення «яка належить нам (собі), яка є в нас (у себе), якою ми користуємося, яка складається 3 нас». Однак, інодіця «присвійність» звужується до «індивідуального володіння», сприймається як така, що призначена для особистого використання, що спричиняє зміщення план змісту: Країні нелегко, якщуо патріоти люблять тільки свою землю (В. Голобородько).

Концептуалізація ДЕРЖАВИ відбувається в семантичному протиставленні державності / недержавності, як-от: Справа здобуття украӥнської державності - це справа нації украӥнськоӥ, а не якогось класу чи партї (С. Петлюра); За незалежність треба платити, за недержкавністьщзебільме (В. Голобородько).

В афористичній площині спостерігається й актуалізація семантичного наповнення ДЕРЖАВА - ФОРМА ПРАВЛІННЯ - ВЛАДА. Боротьба за право керувати державою - це боротьба за владу, за політичне панування, що подекуди відображає стан суспільства, у якому відсутні закони, немає певних обов'язкових норм поведінки і т. ін.: Якщуо вертикаль влади вища за правду, в краӥні похмуро (О. Домницький); Чиновник сильний тим, щзо має державну владу на правах приватної власності (В. Шамша); Насправді там правова держава, де у владияів душа не іржава (Д. Свінціцький). Такі афоризми утверджують ідею правової держави, у якій представлена така форма державної влади, за якої панує верховенство правового закону, що перед ним однаковою мірою відповідальні всі (У правових державах керуються не меморандумами, а законами (О. Перлюк); Хороші закони - це щзе не правова держава (О. Домницький); Правова країна та, де важко сісти $і$ нелегко вийти (В. Голобородько). Проте реалії сьогодення викликають зовсім інші асоціації, що сприяло й оновленню афористичного корпусу, як-от: Під здачу держави дають будь-який кредит (В. Голобородько); Народ думає, як заробити гроші, держава - як їх відібрати (С. Коломієць); Що менше в державі законності, то більще в ній юристів (С. Скоробагатько); Сдині закони, яких іщее дотримуються в Украӥні, - цуе закони фізики (Р. Крикун); 
Виграти справу в украӥнському суді - изе все одно, щүо виграти в лотерею (В. Ігнатенко); Краще деяких українських реформ - тільки ӥх відсутність (В. Шамша); Україна: країна з великою питомою вагою маловагомих князьків (В. Голобородько); Українські олігархи мимоволі спростували математичну аксіому: в їхніх загребущих руках сума нулів щзороку приносить мільярдні прибутки (Б. Підопригора); Кредо украӥнських президентів: «Що було, то було», «Що маємо, те маємо», «Що буде, те буде» (М. Левицький); Розбудова держави закінчується ї̈ обкраданням (Ю. Рибников); В країні зараз практично лише одна форма власності - награбована (О. Перлюк).

Кажуть, що правова держава $є$ альтернативою авторитаризму, тоталітаризму й анархії та передбачає демократизацію суспільства, установлення такої форми політичного ладу, за якої верховна влада належить народові. 3 огляду на нинішню ситуацію в Україні хіба що лінивий не говорить про демократичну державу й демократію. Відповідно, семантичне наповнення ДЕРЖАВА - ДЕМОКРАТІЯ мало б викликати цілком позитивні емоції (Демократія тим і добра, щзо при демократї не держава руйнує людину, $а$ людина будує державу (Л. Костенко). Натомість, афористична репрезентація відповідної реалії засвідчує індивідуально-авторське потрактування, що суперечить загальноприйнятому витлумаченню: Демократія - це коли вся влада належить народові, а всі органи влади - олігархам (О. Перлюк); Демократія - изе коли за кого не проголосуй, краӥною будуть правити олігархи (О. Перлюк); Демократія - иче влада олігархів плюс лохалізація всієї краӥни (О. Перлюк); Демократія - цее влада олігархів плюс бандитизація всієї країни (О. Перлюк); Демократія зайшла далеко, але нас посилають щзе далі (С. Коломієць); Демократія поглибилась настільки, щуо ї̈ вже й не видно (О. Перлюк) і т. ін.

Знайомство, зв’язки, що використовуються в особистих інтересах, потурання своїм друзям і родичам на шкоду справі (Чесний чиновник від держави собі нічого не бере, а все віддає своїм дітям (В. Ігнатенко); Від улюблених чад правителів вже $i$ в державі чадно! (Г. Яблонський), активне 
противенство, зіткнення між протилежними соціальними групами, станами, протилежними напрямками i т. ін. призводить до непорозумінь, розчарувань i хаосу (Вічна парадигма історії: за свободу борються одні, а до влади приходять інші (Л. Костенко); Українське суспільство справді розколене на два непримиренні табори: одні громадяни не люблять наших політиків, іншіненавидять (С. Скоробагатько), що може мати значно негативніші наслідки утрату незалежності, яку виборювало не одне покоління, чи то втрату територіальної цілісності: Ми щзо не виборем, то втратим, $і$ в ц̧ьому вся нама біда (Л. Костенко); Отримали Украӥну без бою $і$ здають без бою. А втім, чого без бою? Б’ються поміж собою (Л. Костенко); Яку державу ми будуємо? Цього не знають навіть ті, хто ї̈ руйнує (В. Шамша); Крим буде українським - або безлюдним (Д. Корчинський); Поки Украӥна буде напів-Росією, в ній буде повний бардак (В. Голобородько).

Кожен справжній українець, законослухняний громадянин своєї держави, повинен пам'ятати загальновідомі істини: Наша сила - в єдності, а порука успіху наших змагань - у державній слухняності (С. Петлюра); Державу треба будувати з підмурка, щуоб кожен свою цеелинку поклав. А з того каміння, щуо за пазухою, держави не збудуєш (Л. Костенко). Державні ж очільники, аби повернути собі довіру народу, мають передусім «реформувати» себе, добре усвідомлюючи те, щолише Ti держави здатні стати великими, у яких великі малі люди (О. Довженко) і Якщуо в краӥні нічого не змінюється, змінюється ставлення до тих, хто обіцяв все змінити (О. Перлюк).

В афористичному просторі досить рельєфно представлено семантичне наповнення ДЕРЖАВА - НАЦІЯ, ДЕРЖАВА - НАРОД, ДЕРЖАВА - ЛЮДИНА, ДЕРЖАВА - УКРАЇНЕЦЬ, ДЕРЖАВА - РАБі т. ін.: Доля украӥнськой мови - то $є$ водночас й доля украӥнської держави й нації (І. Лосєв); Народ побачив натовп біля державного корита (Л. Забара); Невже тоді, коли народ обере олігархів керувати державою, влада стане народною? (О. Домницький); Чи можна зробити державу багатою, якщуо люди в ній бідні? (Б. Слюсар); Виборцюю, голосуй так, щуоб на гербі України замість тризуба не з'явилися граблі! 
(Б. Ревчун); Народ, який народжує «нових» українияів, безсмертний (В. Голобородько); Мрія держави - иілком здоровий, заможний громадянин, який завжди вчасно сплачував податки $i$ помер у день виходу на пенсію (С. Скоробагатько); Кожен украӥнец̧ь - и̧е «троїсті музики»: одне - думає, друге - каже, третє - робить (I. Драч); Украӥниям важче за всіх: їм треба видавлювати із себе не тільки раба, а щзе й гетьмана (В. Шамша); Чим більш рабів є в Україні, Тим більще слави у Москви (С. Горлач). Такі афоризми «мають універсальну адресацію й реалізують комунікативні завдання повідомлення нових знань чи апеляції до наявних у когнітивній базі учасника комунікативного акту» [Колоїз 2014 : 83], транслюють ціннісно-нормативну систему, сформовану у процесі розвитку суспільства.

Подекуди концепт ДЕРЖАВА маніфестується крізь призму семантичної сфери ДЕРЖАВА - МИ, наприклад: Якщуо держава - изе ми, то хто тоді вони? (Ф. Боднар); Ми вже як той сухогруз, щзо недавно розломився у Чорному морі. Одну частину відносить у бік Свропи, друга дрейфує до Росї. А на вцілілій кормі матроси варять борш⿻(Л. Костенко); Розп'ято нас між Заходом $i$ Сходом. Що не орел - печінку нам довбе. Зласкався, доле, над моїм народом, Щоб він не дався знівечить себе (Л. Костенко); А щзо Москва? Москві немає діла. Ми - щуит Свропи і свій хрест несем. Хіба йй щзо? Вона іщуе й зраділа - де двоє б’ються, третьому хосен (Л. Костенко). У такому разі авторське ми усвідомлюється як «я + інші» й протиставляється займенниковій формі вони, що інтерпретується як «інші»: Це не держава винна, ице ті, кого вони обрали за своєю подобою (Л. Костенко). Універсальність подібних афористичних висловлень визначається тим, що «кожен адресат має змогу ототожнити себе із суб'єктом ситуації» [Колоїз 2014 : 83].

Доволі часто семантичне наповнення аналізованого концепту в афористичному просторі увиразнюється за рахунок прикметника український, як-от: Українська народна гра: лобом об лоб - хто далі відскочить? (В. Шамша); Украӥнська влада вміє користуватися не лище батогом - якщзо треба, може і пряником так уперіщуити! (Р. Крикун); Еволющія українського 
політика: прийшов, побачив... перебіг в іншу партію (С. Коломієць); Щоб розмовляти украӥнською, потрібна мужність, російською - досить нахабства (В. Голобородько). Або навпаки, лінгвальне осмислення відповідної реалії відбувається 3 використанням прикметникового деривата державний, що досить рідко маніфестує своє словникове значення («який має важливе значення для держави, може впливати на стан іï справ; який бере безпосередню участь у керівництві державою»). Пор.: $B$ країні дурнів $i$ хамів різновид державного устрою не має великого значення (В. Голобородько); 3 появою злочинщів у законі утверджується й державний бандитизм (Л. Забара); Чим більше державного майна розпродується, тим більи продажна держава (В. Ігнатенко); Якщо $і$ далі так розбудовуватимемо державу, то в ній не залишиться нічого державного (В. Дугар); Найкраща держсавна мова - езопова (В. Шамша). Паремії, у структурі яких наявний компонент державний, вирізняються досконалою художньою формою, що забезпечується використанням різних стилістичних ресурсів. У цьому плані заслуговує на увагу передусім метафоризація, яка репрезентує асоціативно-образне сприйняття певної реалії: Одні тягнуть державного воза, інші їх критикують, сидячи на возі (С. Коломієць); На нашому державному кораблі - доморощені пірати (Л. Забара); Тонучий держсавний корабель першою покидала злочинна кают-компанія (Л. Забара); Чим більше людей обслуговує держсавну машину, тим гірше вона прац̧ює (I. Токарчук); Чим більще гвинтиків у державній машині, тим гучніме вона торохтить (Ф. Боднар) і т. ін. Держава асоціюється 3 певними засобами пересування, механізмами, які передбачають «керманича», того, хто ними керує, обслуговує.

Стилістичний ефект досягається й за рахунок виокремлення семи слова 3 переносним значенням: Для тих, хто має доступ до державного корита, держава - ие святе! (О. Перлюк); Скільки точок зору! А об’єкт одиндержкавне корито (С. Коломієць); У державної корівки - иуілорічний період лактащіï (Л. Забара). Подібні афоризми засвідчують оригінальне авторське світобачення, а деінде сприймаються як ті чи ті індивідуально-авторські 
трансформації узуальних пареміологічних одиниць (власне паремій чи інших афористичних висловлень): Скільки вовка не годуй з державного бюджету, $а$ апетит до народного добра у сіромания тільки зростає (Б. Підопригора); Сильній державі розум не треба (В. Голобородько); Любов до Украӥни не звільняє від любові до Кримінального кодексу (В. Шамша); Украӥна у нас одна. А скільки гетьманів! (В. Шамша); Українцям нічого втрачати, окрім свого Чорнобиля (А. Закревський); Корумпована країна з порядним президентом бочка дьогтю з ложкою меду (А. Закревський); Країна дурнів не така вже й дурна: коней міняе на переправі, щзоб життя швидие ставало кращим (В. Голобородько); Дурням закон не писаний, тож у краӥні дурнів парламент зайвий (В. Голобородько); Украӥна: доки сонц̧е демократї зійде, роса плутократії очі виїсть (Б. Ревчун).

Подекуди різні модифікації (і не тільки!) супроводжуються прийомом несподіваної / неочікуваної розв’язки або паремія загалом маніфестує парадокс як результат фактичних суперечностей: Країна знає своїх героїв по сторінках кримінальних справ (Ю. Рибников); Ситуація в країні під контролем: корупцุіонерів, рейдерів, бандитів, наркоманів (О. Перлюк); Скільки в краӥні енергійних, грамотних, непримиренних бориів за місиее біля корита! (С. Коломієць); Справжня демократія - цуе коли в країні кілька генпрокурорів, десяток грабіжників-олігархів, тисячі корупщіонерів та жодного винного (О. Перлюк); Коли в краӥні немає порядку, для корупщіонерів щзе - ідеальний порядок (С. Коломієць); Не можна сказати, щзо народ в країні абсолютно нічого не вирімує, наприклад, він постійно вирішує - як йому вижити (О. Перлюк); Краӥна багатіє людьми, які живуть за межею бідності (А. Максимець); Ми живемо в країні парадоксів: народжуваність падає, смертність зростає, а житло рік y рік дорожчає ци дорожчає (С. Скоробагатько).

Українськомовний афористичний корпус репрезентує досить широкий семантичний спектр концепту ДЕРЖАВА. До того ж семантичний вектор модифікується, афористичні висловлення апелюють до проблем, 
актуалізованих в умовах сьогодення, передусім до проблеми захисту державного суверенітету й територіальної цілісності: Маємо претензії до Бога, щуо не дає нам України. Маємо претензії до ворогів, щуо гарбали від нас, скільки могли. Маємо претензї до світу, щзо нас не оборонив і не боронить. Не маємо претензій тільки до себе (Р. Купчинський). Сьогодні Україні потрібна ефективна (порядна) державна влада. Натомість, Поки щзо в Україні порядку й порядності на порядок менше, ніж у порядних краӥнах (Б. Ревчун). I досить актуальне, хоч і давнє висловлення: Проблема Украӥни в тому, щзо нею завжди керують люди, яким вона не потрібна (М. Грушевський). Проілюстровані афоризми спонукають до осмислення загальнолюдських цінностей i національних пріоритетів, що відповідають моральним запитам суспільства загалом i людини зокрема. А концепт ДЕРЖАВА потребує грунтовного лінгвоментального осмислення. I не лише в афористичному просторі. До того ж афористичні висловлення, що маніфестують концепт ДЕРЖАВА, є цікавими 3 погляду прагматики та стилістики.

\section{БІБЛІОГРАФІЯ}

Колоїз 2014 - Українська пареміологія : [навчальний посібник] / Ж. В. Колоїз, Н. М. Малюга, Н. М. Шарманова ; за ред. Ж. В. Колоїз. - [2-е вид., стереотип.]. - Кривий Ріг : ДВНЗ «КНУ», 2014. - 349 с.

Семененко 2011 - Семененко Н. Н. Русские паремии : функции, семантика, прагматика : [монография] / Н. Н. Семененко. - Старый Оскол :ИздBo POCA, 2011. - 355 c.

Ужченко 2007 - Ужченко В. Д. Фразеологія сучасної української мови : [навчальний посібник] / В. Д. Ужченко, Д. В. Ужченко. - К. : Знання, 2007.494 c. 